\title{
Chinese Enterprise Risk Management_-Based on the Application of Financial Derivatives
}

\author{
Chengyong Liu ${ }^{1, a^{*}}$ and Cheng Chen ${ }^{2, b}$ \\ ${ }^{1}$ Beijing Institute of Technology, Zhuhai, Guangdong, 519088 China \\ ${ }^{2}$ National Taiwan University, Taipei 10617, Taiwan, China \\ a liucy13@126.com, ${ }^{b}$ legalcici@gmail.com \\ * The corresponding author
}

Keywords: Financial derivatives; Risk management; Project management

\begin{abstract}
In the 21st century, global derivative financial products have been greatly developed. Both transaction scale and derivative financial product innovation have reached a relatively prosperous era. In fact, financial derivatives are essentially a sharp double-edged sword. If the enterprise is used properly, it will bring huge economic benefits to the enterprise. However, if there is excessive abuse or non-subjective operational errors, it will be invisible. The consequences of the risk of serious amplification of the company. Therefore, based on the perspective of financial derivatives and risk control of Chinese enterprises, this paper briefly analyzes the motives of enterprises using financial derivatives, and then combines the current situation and the crux of the financial derivatives in China's enterprises in risk management. The perfect measures of derivatives in the application of enterprise risk management in China, in order to make full use of its two-sided characteristics, to avoid disadvantages.
\end{abstract}

\section{Introduction}

In the era of highly developed financial markets, traditional financial instruments have been unable to meet the ever-changing financial management needs of enterprises. Faced with the drastic fluctuations in the prices of commodity markets and the continuous increase in interest rate exchange rate risks, the importance of corporate financial management to corporate financial managers in China has continued to increase. The role of derivative financial instruments in the management of corporate financial risks has also become increasingly prominent. The financial market environment determines that modern financial management must actively and fully use derivative financial instruments to optimize financial risk management. The basis for the development of derivative financial products in the international market is the developed long-term and futures markets, while the domestic long-term market is relatively underdeveloped. The external and internal conditions of enterprises are tied up in the use of derivative financial instruments for financial risk management in financial management. Therefore, it is of great significance to vigorously develop derivative financial products under the state's macro-control and to help enterprise risk management. The article introduces the concept, characteristics and functions of derivative financial instruments. Combined with the theory of enterprise risk management, it puts forward that the use of derivative financial instruments in financial management can not only avoid financial risks, realize the preservation and appreciation of funds, but also facilitate investment and financing. Uncertain capacity and resilience, but also can enhance the company's core competitiveness, realize the view of risk and opportunity, cost and profit optimization.

\section{The Function of Financial Derivatives}

In today's financial markets, the use of financial derivatives is very common and has achieved great success. This is obviously a very deep connection with the unique features it has. Its functions are:

The Completeness of the Market (Completeness of Market). financial economic theory that, in an ideal full market, each risk state has a corresponding tradable gains(the so-called 
Arrow-Debreu price). The arbitrage-free equilibrium will only be achieved in a complete market. Derivatives increase the integrity of the market with its rich revenue structure, enabling the market to achieve an arbitrage-free equilibrium.

Speculation (Speculate) Derivatives are often Known for High-risk Transactions Characterized by its High Leverage is one of the Main Reasons. For investors, holding the corresponding positions of one or more derivatives can allow them to speculate on the rise and fall of interest rates, the overall stock market but only the rise and fall of stocks, and the rise and fall of a country's currency exchange rate. To maximize cost and maximize revenue. However, it must be noted that the speculation of derivative products must be moderate, and excessive speculation may cause violent fluctuations in the market, leading to serious consequences.

Risk Management. Derivatives provide a very important and effective management tool for market players who want to avoid risk. To give a simple example, a company that intends to issue bonds faces interest rate risk. If the market interest rate rises before the bond is officially issued, the company will have to accept this than the original planned interest rate, and thus Bear higher interest payments. In this case, the company can pre-empt the interest rate risk by buying interest rate futures to obtain a predetermined issue rate.

Reduce Transaction Costs. Derivatives are Derived from Certain underlying assets (base assets), so in Many Cases, investors can Hold one or More Derivatives as an Alternative to the Position of the Underlying Asset. For example, a stock index position can be a good copy of the underlying stock index, and an interest rate futures contract can be used as a substitute for its underlying treasury portfolio.

\section{The Impact of Derivative Financial Instruments on Enterprise Risk Management}

The financial management of an enterprise is the operational management of the company's funding sources, capital investment and market risks. In financial management, the management of the cost and benefit of funds and risk is the core.

Improve the Efficiency of Corporate Capital Operations. In enterprise management, the use of funds needs to balance security and profitability. Enterprises can find the appropriate financial instruments through the physical financial market and derivative financial market to achieve the purpose of improving the efficiency of capital operations and reducing financial costs. Through the analysis of financial statements, the company obtains information on the company's operating capabilities, debt capabilities, asset flow ratios, and quick ratios, and analyzes the demand for financial derivative products. In corporate fundraising, whether it is direct financing or indirect financing, companies can use financial derivative tools to reduce the cost of capital or lock in risk, and at the same time solve the problem of deadlines and currency mismatches in financing; in corporate investment management, finance Derivatives can provide companies with more flexible directions and higher returns.

Reduce Financial Risks. Financial risk management refers to the identification, measurement and analysis of various risks existing in the economic operation process of the operating entity, and adopts timely and effective methods for prevention and control, and is handled in an economically reasonable and feasible way to ensure the safe and normal operation of business activities. The management process that guarantees its economic benefits from loss.

What companies need to achieve in financial management is to obtain the maximum benefit under the minimum risk. Derivative financial instruments have features such as high leverage and market mismatch, which can provide effective operational tools for enterprise risk management. Financial derivative products can select basic financial assets and related transaction structures based on the market risks the company is facing. Through cross-period transactions or hedging transactions, the risks of future market price fluctuations, including exchange rates, interest rates, commodity prices, etc., can be locked.

Optimize the Allocation of Resources. The risks of financial derivatives in business management can be quantified and measured. The participation of enterprises in the financial derivatives market within the risk tolerance category is the optimization of financial risk 
management. We know that the benefits and risks are positively correlated. If the risk is too high, it will obviously bring danger to the company. The operation with too low risk factor will also bring about low-efficiency operations with low capital utilization rate or high hedge costs.

\section{The Scope of Application of Derivative Financial Instruments in Corporate Financial Management}

Application of Derivative Financial Instruments in Corporate Financing. As the main business entity in the market, the financing cost of the enterprise largely determines the operating capacity and profitability of the enterprise. Simple indirect credit financing relatively speaking, the cost of capital is relatively high. At the same time, affected by the scale of bank credit, companies may be relatively untimely in obtaining loans. Direct financing in the primary market can not only reduce the cost of capital, but also the successful issuance of financial bonds in a certain sense also reflects the strong strength of the enterprise and enhances the visibility of the enterprise. However, direct financing also has the impacts of long tune cycle, cumbersome preparation materials, restrictions on the use of funds, and the company's own rating. In some respects, it has been unable to meet the requirements of modern companies to reduce financing costs and improve the efficiency and convenience of financing as much as possible. In the highly developed financial market environment, the demand and choice of funds for enterprises are various. The financing decisions of an enterprise can be managed and implemented based on the period of use of the funds, their use, and their existing capital structure.

The Application of Derivative Financial Instruments in the Value-added of Enterprise Investment. In addition to the management and optimization of cash flow in the process of enterprise production, the management of enterprises is more and more important. The investment of enterprises is more and more prudent and conservative. Because of the enlargement of the production scale of the main industry, the investment demand of the financial products is becoming more and more big. In particular, the financial funds of some enterprises require higher profitability and higher liquidity and security, and their demand for investment risks is more stringent. The perfect combination of pure banks to public financial products and trust products is often difficult to achieve high returns and low risks, and the desire for enterprises to participate in the financial market is becoming more and more intense. Commercial banks can meet the personalized needs of the enterprises, match the corresponding derivative financial tools, design the transaction structure, in a more flexible way, more broad investment direction and higher value return for the enterprise to bring value-added services to the enterprise.

Application of Derivative Financial Instruments in Business Management. The financing cost of financing for enterprises depends to a certain extent on changes in market interest rates. The volatility of the interest rate market may cause changes in the company's existing cost and return on assets and liabilities. This change has led to great uncertainties in the production and operation process. Through derivative financial instruments, costs and benefits can be optimized under certain conditions. Holders of floating interest rates are often at risk of uncertainty, while a single fixed interest rate appears to be deterministic, but more and more companies realize that they have lost the opportunity income from interest rate changes. Judging from different market conditions, different trading strategies have made companies strong demand for interest rate markets.

\section{The Improvement of Financial Derivatives in the Application of Enterprise Risk Management in China}

Some enterprises in China have experienced huge losses due to transactions in financial derivatives, which made the company once on the verge of economic collapse. Therefore, the application of corporate financial derivatives in risk management should not be underestimated. The duality and concealment of the risk of financial derivatives makes the relevant personnel of the enterprise slightly negligent, which will cause the economic losses that the enterprise can not make up. 
Therefore, enterprises should pay attention to the analysis and control of the above problems to better control Take advantage of financial derivatives to better serve the business.

Strengthen the Comprehensive Construction of Enterprise Risk Management and Control System. When engaging in financial derivatives trading, enterprises should strengthen the overall risk awareness and optimize the internal control environment; on the other hand, they should also strengthen the supervision of ex-ante, in-process and post-event projects. For market risk, internal management risk and exchange rate risk, we must correctly identify, evaluate, and timely handle, establish a sound early warning system, linkage and cooperation between the rules and regulations and organizational departments, and maximize the comprehensive quality of personnel construction. Realize the practical effectiveness of enterprise risk management to provide effective protection.

The Original Intention of Strictly Observing the Hedging of Financial Assets. The continuous development of the financial market is inseparable from all kinds of market participants. However, the vast majority of financial market participants in China still invest in the concept of hedging risk based on hedging. All types of companies should clearly understand that: Only by rationally selecting appropriate value-preserving products and matching quantity and time, can we try to evade the temptation of benefits and reduce speculative risks in real operations, and thus rely on ideas and operations. And rules and regulations guide companies to rationalize the benefits of financial derivatives.

Paying Special Attention to the Construction of Comprehensive and Comprehensive Professional Talents. The comprehensive soft power construction of personnel is crucial to the survival and development of the company. First of all, the leaders of enterprises should attach great importance to them to further improve the effectiveness of financial investment and risk management. In addition, the realization of industry development and enterprise-oriented intellectual protection also requires that enterprises should strengthen the function of the financial derivatives market practitioners and improve the overall quality. Only by realizing the comprehensive popularization of high-level education for financial market practitioners can it be more conducive to safeguarding the maximum limits of the effectiveness and functions of enterprise risk management.

Vigorously Promote the Improvement of Internal and External Regulatory Policies. Strengthen industry self-discipline, further improve the access system for financial derivatives market, improve the risk monitoring system, strengthen the information disclosure system, and coordinate the coordination mechanism of the main body, accelerate the convergence of industry standards with the international market, and use timely consultation mechanisms to strengthen communication. Mutual assistance and cooperation can timely resolve market risks and avoid corporate risks, so as to promote the stability and sustainable development of financial markets more rationally.

\section{Conclusion}

Derivative financial products provide an effective financial tool for enterprise management, which is of great significance to the company's capital operation and risk management. Expanding the scope of application of derivative financial products, improving the quality of financial risk management personnel, establishing an operating system for derivative financial products within the enterprise, and participating in the derivative financial product market can create value for the enterprise when the enterprise has sufficient risk awareness. It is the inevitable development of financial market that enterprises change their financial management concepts in financial management and attach importance to the use of derivative financial products to better manage financial risks. It is hoped that the application of derivative financial instruments in China's enterprise management will continue to develop and accept market testing. It is also hoped that relevant research will be more in-depth and make greater contributions to the development of derivative financial instruments and derivative financial markets. 


\section{References}

[1] Branka Tuškan. The use of financial derivatives in risk management in the Republic of Croatia[J]. Zbornik Ekonomskog Fakulteta U Zagrebu, 2009.

[2] Li W, Wen D. Notice of RetractionCases study on the application of derivatives in exchange rate risk management in foreign-related enterprises[C]// International Conference on $\mathrm{E}$-Business and E-Government. IEEE, 2011.

[3] Lian-Hua L I, Yang C J, Finance S O. Empirical Analysis on the Effect of Financial Derivatives__ From the Perspective of Risk Management of Cash Flow[J]. Collected Essays on Finance \& Economics, 2014.

[4] Falco M D, Stasi D D. Financial derivatives for risk management in shipping operations: A simulation model applied to the oil and gas sector[C]// International Conference on Advanced Logistics and Transport. IEEE, 2014:336-343.

[5] Hayes J A, Cole J B, Meiselman D I. 1993: Health Insurance Derivatives: the Newest Application of Modern Financial Risk Management[M]// The Best of Business Economics. Palgrave Macmillan US, 2016:36-40.

[6] Ying $\mathrm{H}$ E. Use of derivative financial instruments in market risk management_— Based on petroleum trade enterprises[J]. International Petroleum Economics, 2016.

[7] Jiang P J, Jin S P, Amp C G. The application of financial derivatives in the management of cash flow in international trade[J]. Technological Development of Enterprise, 2015, 7(2).

[8] Tashfeen R, Azhar T. Is Bigger Better? Firm Size Implications of Corporate Governance Risk Management Over Financial Derivatives[J]. Social Science Electronic Publishing, 2017.

[9] Zivanovic B, Mina K. The usage of financial derivatives in financial risk management by nonfinancial companies in Serbia[J]. 2017, 45(3):65-82.

[10] Qian L I, Zhang X Y, Economics S O. Research on transaction risk and countermeasures of ETF Option:a case of 50 ETF Option in SSE[J]. Journal of Shenyang University of Technology, 2016.

[11]Zakaria S. The Use of Financial Derivatives in Measuring Bank Risk Management Efficiency: A Data Envelopment Analysis Approach[J]. Asian Academy of Management Journal, 2017, 22(2):209-244.

[12]Liu Y J. A Study on the Governance Effect of Commercial Banks' Financial Derivatives_-From the Perspective of Risk-hedging and Corporate Performance[J]. East China Economic Management, 2017.

[13] Du X, Lai S. Financial Distress, Investment Opportunity, and the Contagion Effect of Low Audit Quality: Evidence from China[J]. Journal of Business Ethics, 2018, 147(350):1-29.

[14]Zakaria S. The Use of Financial Derivatives in Measuring Bank Risk Management Efficiency: A Data Envelopment Analysis Approach[J]. Asian Academy of Management Journal, 2017, 22(2):209-244. 